\title{
Wintering Bird Diversity and Population Sizes at Obruk Dam Lake (Corum) in Turkey
}

Kadir Ulusoy ${ }^{(\mathbb{D}}$ and Safak Bulut ${ }^{\mathbb{C}}$

Hitit University, Department of Molecular Biology and Genetics, Corum, Turkey

\section{ABSTRACT}

Tn this study, species diversity of waterbirds, which are the indicator species of wetland 1 quality were investigated at Obruk Dam Lake in Turkey, which was built in 1996 and started to operate in 2009. Obruk Dam built on River Kızılırmak within Çorum province has created a new habitat for waterbird with a lake surface area of $50 \mathrm{~km}^{2}$. As a result of the studies, 21 waterbird species belonging to 6 orders were identified. According to the results of the mid-winter waterbird census revealed in 2018 and 2019, 26.975 and 13.158 individuals of waterbirds were counted in Obruk Dam Lake respectively and it has been proved that the Obruk Dam Lake forms a new terrain especially for birds. Although the census for the year 2020 could not be done completely due to adverse conditions, short observations in 2020 show that the Obruk Dam Lake continues to be used intensively by waterbirds. During the research, intensive and off season hunting activities were observed in the field. In this context, studies have been initiated to keep the censuses continuous in order to monitor the status of the new wetland formed by the Obruk Dam Lake and the waterbirds which are using this wetland.

Keywords:

Benefits of dams; Wetlands; Biodiversity; Bird Census; Waterbirds.
Article History:

Received: 2020/11/01

Accepted: 2020/12/20

Online: 2020/12/31

Correspondence to: Kadir Ulusoy, Hitit University, Department of Molecular Biology and Genetics, 19030, Corum, Turkey E-Mail:kadirulusoy@hitit.edu.tr Phone: +903642277001 Fax: +903642277005

\section{INTRODUCTION}

W Wetlands are ecosystems with a high biodiversity that allow their inhabiting species to carry out their basic vital activities such as feeding, sheltering and breeding [1]. Identification of wetlands cannot be easily achieved due to variations in the occurrence of birds and vegetation, variable water regimes and ranging from inlands to marine waters [2]. Although the definition of wetlands may vary, the most widely accepted definition in the world is the one included in the RAMSAR Convention [3]. According to international Ramsar Convention wetlands are defined as "...areas of marsh, fen, peatland or water, whether natural or artificial, permanent or temporary, with water that is static or flowing, fresh, brackish or salt, including areas of marine water the depth of which at low tide does not exceed six meters..." and waterbird is defined as "...birds ecologically dependent on wetlands..." [4].

Different types of wetlands increase the ecosystem diversity, and in return, species using these wetlands increase biological and genetic diversity $[5,6]$. Although wetlands are important hotspots for the conservation of biodiversity, they cover less than $2 \%$ of the continental surface on earth and continue to shrink [7]. Changes in land use such as urbanization and conversion to agricultural land due to population growth causes wetland decreasing in proportion to the increase in human population [8]. Turkey has a significant amount of wetlands compared to continental Europe. Although wetlands that exist in Turkey are known to be important for breeding and wintering bird species, information about the populations of bird species using these areas are limited [9]. Waterbirds are considered as indicators of wetland quality and restoration as parameters of local biodiversity, and many ecologists think that birds are one of the visible indicators of total productivity of biotic systems [2].

Mid-Winter Waterbird Census (MWWC) is one of the main methods used for long term monitoring of the changes in wetlands, as well as detecting changes in waterbird populations. MWWC was made at 1967 in Turkey for the first time and with the participation of national and international institutions and nongovernmental organizations 34th was in 2018, 35th MWWC was made in 2019 [10].

Dam constructions change the environment by creating an artificial lake area on rivers, which may af- 
fect the biota present in the area before the construction. Waterbird populations vary under the influence of different factors such as water quality in dam lakes, depth of water, vegetation structure around the lake area, fishing, and water sports [11]. Dam lakes and ponds can create different alternative habitats for waterbird, as well as respond to the different ecological needs of different species thus increasing the diversity of species in the area [12]. Research results in Karkamış Dam Lake showed that the new wetland ecosystem created by the dam construction has significantly increased the biodiversity in the area. Censuses on waterbird resulted in the count of 118,434 individuals in 2005, and 73,964 individuals in 2007. After these results, the newly formed wetland ecosystem was included to the "Important Bird Areas of Turkey, 2004 update" [13, 14].

Obruk Dam Lake, the study area, was put into operation in 2009 with a $50.21 \mathrm{~km} 2$ maximum lake area [15] forming a new wetland ecosystem. During the field visits in Obruk Dam Lake, it was determined that the area was started to be used by waterbirds and the purpose of this study is to identify these waterbird species.

\section{MATERIAL and METHOD}

\section{Study Area}

Obruk Dam Lake is located on Kizılırmak River, covering an area of approximately $50 \mathrm{~km}$ long in the southwestnortheast direction, with respect to the flow direction of the river (Fig. 1). The dam is surrounded by the districts of İskilip, Oğuzlar and Dodurga in northwest and the districts of Laçin and Çorum (Center) in southeast. The closest settlement area to the dam shore is the Oğuzlar district, which is on average $2.5 \mathrm{~km}$ away. The ÇorumÇankırı D180 highway passes over the dam by a bridge from the upstream part of the dam, and the road that provides access to the Oğuzlar district passes through the downstream part.

The general vegetation structure consists of deciduous forests and sparse larch forests. In the vicinity of the lake, dry farming, fruit production and greenhouse cultivation

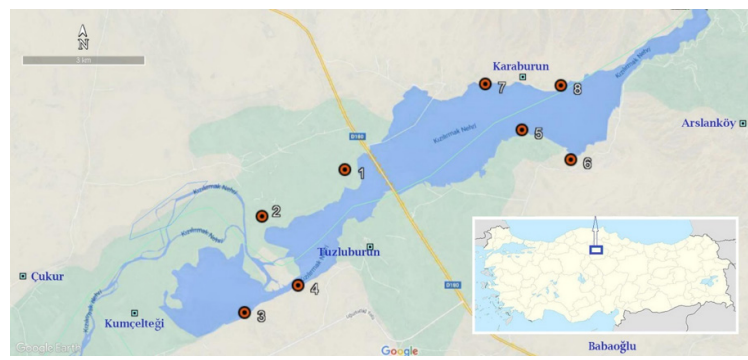

Figure 1. Satellite Image of Point Transect Locations on the Google Earth image. are carried out as well these, irrigated agriculture by dam water exists. It was also observed that cattle and ovine breeding were carried out in the surrounding villages. There are reeds densely in the lake area between Kumçelteği, Karlık and Tozluburun villages in the southeast of the bridge that passes over the lake. Although the lake shores are generally bare due to anthropogenic effect, there are partly reeds in the regions where the seasonal flowing streams reach the lake. In Obruk Dam, commercial fishing is allowed with a hunting quota determined by the cooperative. During the field trips, we also witnessed illegal waterbird hunting.

\section{Waterbird Census}

Canon EOS 7D Mark II DSLR digital camera, Canon 100/400 mm L and $400 \mathrm{~mm}$ L lenses, Nikon Aculon 10x42 binoculars, Nikon 20-60x50 field scope, DJI Phantom 4 Pro drone, and mechanical counters were used during censuses. In the field studies, bird species are identified according to Heinzel et al [16] and Porter et al [17]. Observed bird species together with the census results were recorded in the field notebook. Bird Censuses were made in 2018 and 2019, in January. In January 2020 a short monitoring and census was done to check the current status of study area because of bad weather conditions, low visibility, difficulties to access to the observation points by reason of muddy roads, and continuously movements of waterbirds due to hunting activities. Depending on these reasons census in 2020 was done from only 3 vantage points and condition of wetland was observed.

Field studies were done by using point transect method $[18,19]$. Line transect method was carried out by boat on the lake in order to determine the locations where waterbird colonies are used extensively, and the point transects were made out from 8 vantage points (Fig. 1). The satellite image of the locations where the point transects made are shown in Fig. 1 and their coordinates are shown in Table 1. A total of 8 vantage points were decided due to both of topographic structure of the lake shore and vantage points' view of field. The length of lake area using by waterbirds are approximately $13 \mathrm{~km}$ long and the widest area of lake is about $3 \mathrm{~km}$ long. Because of these situations, we used the points that have the characteristics of having a wide view of the lake area, the clear viewing angles of the shores and existence of waterbird colonies at the vantage points we chose. During the vantage points were determined, the viewing angle of each point and the area to be observed from each point were predetermined, and necessary precautions were taken to prevent the census results from being adversely affected by possible duplicate counts. We have counted waterbirds one by one using mechanical counter and field scope from right to left in view from vantage points. Waterbirds that moves in the opposite of the counting direction were included to 
Table 1. UTM Coordinates of Point Transect Locations

\begin{tabular}{ccc}
\hline Location No & East & North \\
\hline 1 & \multicolumn{2}{c}{$36 \mathrm{~T}$} \\
\cline { 2 - 3 } 2 & 631893 & 4498132 \\
3 & 629901 & 4496954 \\
4 & 629541 & 4494626 \\
5 & 630824 & 4495309 \\
6 & 636208 & 4499195 \\
7 & 637408 & 4498491 \\
8 & 635293 & 4500302 \\
& 637151 & 4500306 \\
\hline
\end{tabular}

census; in order to prevent recounting of waterbirds flying or changing location, individuals which changed their place in the direction of counting were not included in the results.

Entire observation areas and the waterbird colonies in the observation areas were photographed by a DSLR camera with a $400 \mathrm{~mm}$ lens mounted before censuses at predetermined locations. The images were combined with Adobe Photoshop CS3 Extended PC software to create a panoramic view of the observation areas, and the "count tool" in the same PC software was used for carrying out the waterbird censuses.

\section{RESULTS}

The waterbird census results are given in Table 2. Aythya ferina (Common pochard) is listed as "VU=Vulnerable", Numenius arquata (Eurasian curlew) and Turdus iliacus (Redwing) are listed as "NT=Near Threatened"; and remaining 18 waterbird species are listed as "LC=Least Concern" according to the IUCN (International Union for Conservation of Nature) RedList [20]. In terms of Bern Convention (Convention on the Conservation of European Wildlife and Natural Habitats) 6 species are listed in Appendix II (Strictly protected fauna species), 15 species are listed in Appendix III (Protected fauna species) [21].

14 waterbird species from 6 orders were identified in Obruk Dam Lake in 2018 winter season and from these species 26.975 individuals were counted with the most common species Fulica atra (Eurasian coot) with 23.772 individuals It was followed by Anas platyrhynchos (Mallard) with 1.151 individuals and Tadorna tadorna (Ruddy shelduck) with 761 individuals, respectively.

In the winter season of 2019, 13.158 individuals from 19 waterbird species were counted, and the most common species was Fulica atra, represented with 10.655 individuals. Census results show that F. atra was followed by Anas platyrhynchos (Mallard) with 1,101 individuals and Anas crecca (Eurasian teal) with 601 individuals. The census results for January 2019 are given in Table 2.

As a result of the field study conducted in January 2020, a total of 11.597 waterbirds were counted in the study area, and the most observed species were Fulica atra with 10.101 individuals and Anas platyrhynchos with 1.062 individuals, respectively. During the short observations, 7 waterbird species were identified belonging to 6 orders. These results also are shown in Table 2.

Two different areas were detected that mostly preferred by waterbirds in Obruk Dam Lake. One of these locations is the shallow part of the area, stretching from the shores of Salur and Karaburun villages to the vicinity of the Kızllırmak Bridge, reaching a depth of about 5 meters and covering an area of approximately $30 \mathrm{~km} 2$. The second location is the reed-bed, which extends from the shores of Tozluburun village to the shores of Kumçelteği village, where the lake area starts.

In the observations, we found that Eurasian coot, Mallard, and Great crested grebe formed colonies together, away from the shores. Cormorant species were usually observed roosting in the submerged tree branches or floating around these trees. Ruddy shelduck usually prefers bare fender areas on the opposite shore of Yalakçay village. Heron species (Great egret, Little egret and Gray heron) were observed roosting on the whole lake shore rather than a specific area.

Our monitoring studies showed that waterbirds do not choose locations like the shores of settlements by the lake and the coastal areas where human activities such as angling, picnic and boat docks regions. There is Kızılırmak Bridge on the D-180 highway which provides transportation between İskilip and Çorum on the lake and divides dam lake into two parts and waterbirds do not use bridge and areas near bridge because of disturbance.

\section{DISCUSSION}

Although, dams built on rivers are damaging the existing ecosystem, they can also provide significant benefits for the ecosystem in case of appropriate physical conditions $[11,13]$. This research aimed to determine the waterbird species wintering in Obruk Dam Lake. In Turkey, MWWC was started in 1967, and censuses are still being conducted annually under the leadership of the General Directorate of Nature Conservation and National Parks (DKMP) [10]. In Obruk Dam Lake, which started to operate in 2009, the first waterbird census was made by Erciyas Yavuz and Kartal (2012) [22]. After the first census, a census was made in the following year by Erciyas Yavuz and İsfendiyaroğlu [23], and no other mid-winter 
Table 1. Winter Waterbird Census Results of 2018 and 2019 and short observation results of 2020

\begin{tabular}{|c|c|c|c|c|}
\hline Common Name & Scientific Name & 2018 & 2019 & 2020 \\
\hline Eurasian coot & Fulica atra & 23,772 & 10,655 & 10,101 \\
\hline Mallard & Anas platyrhynchos & 1,151 & 1,101 & 1,062 \\
\hline Ruddy shelduck & Tadorna ferruginea & 761 & 52 & 48 \\
\hline Great cormorant & Phalacrocorax carbo & 558 & 112 & 126 \\
\hline Black-headed gull & Chroicocephalus ridibundus & 184 & 205 & 63 \\
\hline Great egret & Ardea alba & 104 & 51 & 12 \\
\hline Little egret & Egretta garzetta & 93 & 1 & - \\
\hline Little grebe & Tachybaptus ruficollis & 84 & 165 & - \\
\hline Eurasian teal & Anas crecca & 57 & 601 & - \\
\hline Yellow-legged gull & Larus michalensis & 55 & - & - \\
\hline Northern shoveler & Anas clypeata & 39 & - & - \\
\hline Green sandpiper & Tringa ochropus & 28 & - & - \\
\hline Grey heron & Ardea cinerea & 23 & 14 & - \\
\hline Great crested grebe & Podiceps cristatus & 19 & 132 & 185 \\
\hline Common redshank & Tringa totanus & - & 20 & - \\
\hline Red-crested pochard & Netta rufina & - & 16 & - \\
\hline Common pochard & Aythya ferina & - & 9 & - \\
\hline Common greenshank & Tringa nebularia & - & 8 & - \\
\hline Common shelduck & Tadorna tadorna & - & 2 & - \\
\hline Eurasian curlew & Numenius arquata & - & 2 & - \\
\hline Tufted duck & Aythya fuligula & - & 2 & - \\
\hline Unidentified waterbird & & 47 & $10-$ & - \\
\hline TOTAL & & 26,975 & 13,158 & 11,597 \\
\hline
\end{tabular}

waterbird census was conducted in Obruk Dam Lake until 2018. Results of censuses compared with Mid-Winter Waterbird Census (MWWC) results made by DKMP, it is seen that Obruk Dam Lake is the 13th location from 153 different locations with 26975 waterbirds wintering in 2018 in the ranking of highest number of waterbird counted locations list [3].

According to the results of MWWC in 2019, among 154 different locations with the highest number of waterbird counts, Obruk Dam Lake ranked the 24th with 13.158 individuals [10]. These results clearly show the status of Obruk Dam Lake among the sites hosting the highest waterbird populations in Turkey. This newly formed wetland, created by Obruk Dam Lake, which hosted 26.975 individuals in 2018 and 13.158 in 2019, is an important wintering location for waterbird species in Turkey, as reflected by the census results.

Obruk dam, which is built on Kızılırmak, as a reservoir type has created a new habitat especially for water birds, as in the case of Karkamıs dam, as a result of observations made with. The Karkamıs dam, built in 2000, has been an area visited by more than 20,000 waterbirds on average, alt- hough there are differences in numbers every year. In the studies carried out, 110 bird species were identified in the Karkamıș dam [13]. Obruk dam formed a new habitat especially for waterbirds following the impoundment of the dam, as in the example of Karkamıs dam, and 59 different bird species and 22 different water bird species can be observed.

As a result of the studies carried out in Karaçomak and Beyler dams built in Kastamonu neighbouring province of Çorum, 23 waterbird species from 11 families belonging to 6 orders in total were identified. 17 species belonging to 6 orders in Karaçomak dam and 22 species belonging to 6 orders observed in Beyler dam [24]. When Obruk dam is compared with Karaçomak dam built between 1968-1973 and Beyler dam built in 1993, it is seen that the variety of species and the number of individuals are higher in Obruk dam. These results support that Obruk dam creates a new wetland and a new habitat for water birds.

In Eber and Köyceğiz lakes which are important wetlands of Turkey, 59 waterbird species belonging to 14 orders and 38 waterbird species belonging to 12 orders have been identified respectively [25]. Obruk dam contains 22 waterbird species belonging to 6 orders and approximately half of 


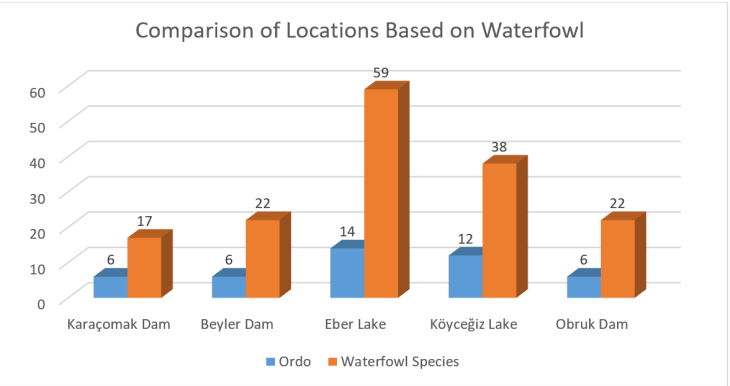

Figure 2. Comparison of Locations based on waterbird species

the species diversity in these areas (Fig. 2).

Intense and illegal hunting is thought to have a higher negative effect on waterbird, reflecting on the behaviour of populations as an avoidance to use the area. Precautions to be taken on this issue have been identified and negotiations have been initiated with the relevant authorities and actions have been started to reduce illegal hunting in the future times. Studies have been started to determine the water quality and water quality will be monitored according to the results to be obtained and if necessary, actions will be planned and implemented which are essential. Results of short observation and limited census in January 2020 shows that Obruk Dam lake wetland is still being used intensely by waterbird actually. The partial increase in the number of individuals proves that the Obruk Dam Lake is a new habitat especially for waterbird and indicates the necessity of monitoring its condition in the coming years.

\section{CONCLUSION}

As a result of the censuses made in 2018 and 2019, as well as the short monitoring carried out in 2020, waterbird species diversity and the number of individuals hosted by the Obruk Dam Lake show that a new wetland has been formed in the Çorum Province. With the construction of Obruk Dam, this wetland has increased the biodiversity of the region, creating new habitats where bird species that did not previously use the area can perform activities such as wintering and feeding.

Our studies in Obruk Dam Lake are important as they provide data about the status of waterbird species in the area for the first time. In this context, mid-winter waterbird censuses will be repeated every year and the relationship between waterbird species and Obruk Dam Lake will be revealed more clearly and precisely.

\section{ACKNOWLEDGEMENT}

This study is the thesis of Kadir Ulusoy which was supported by Hitit University Scientific Research Projects Coordination Unit (FEF19001.17.007). In addition, we would like to thank the graduate student Mujde Fistik for her contributions during the census and Biologist Deniz Candas for her support during the writing of the article.

\section{References}

1. Süllü N. “Konya-Ereğli Akgöl'ün avifaunası” PhD Thesis, Selçuk Üniversitesi institute of science, 2006.

2. Weller MW. Wetland birds: habitat resources and conservation implications. Cambridge University Press, Cambridge, 1999.

3. DKMP, "Kış Ortası Su Kuşu Sayımları 2018”, Ankara, 2018.

4. Ramsar Convention Secretariat, 2013. The Ramsar Convention Manual: a guide to the Convention on Wetlands (Ramsar, Iran, 1971), 6th ed. Ramsar Convention Secretariat, Gland, Switzerland.

5. Tirıl A, Baylan E. Wetland management in Turkey: Problems, achievements and perspectives. African Journal of Agricultural Research, c. 4, sy 11, (2009) 1106-1119.

6. Keten A, Arslangündoğdu Z, Selmi E. Düzce-Efteni Gölü Kuş Türleri. Düzce Üniversitesi Orman Fakültesi Ormancılık Dergisi, c. 8, sy 1 (2012) 10-18.

7. Cruz T, Lima J, Luís A, Azeiteiro UM. Avifauna conservation and disturbance ecology in a coastal freshwater lagoon. Environmental monitoring and assessment, c. 190, sy 10 (2018) 592.

8. Czech HA, Parsons KC. Agricultural wetlands and waterbirds: a review. Waterbirds (2002) 56-65.

9. Perktaş U, Albayrak AB, Ayaş Z. The evaluation of some key wetlands for waterfowl in central Anatolia, Turkey, in: Hanson AR, Kerekes JJ (Eds.). Limnology and Aquatic Birds: Abstracts and Selected Papers from the Fourth Conference of Societas Internationalis Limnologiae (SIL) Aquatic Birds Working Group. Paper presented at Fourth Conference of Societas Internationalis Limnologiae (SIL) Aquatic Birds Working Group, Sackville, New Brunswick, Canada, 3-7 August. Springer. Netherlands, pp. 166, 2006.

10. DKMP, “Kış Ortası Su Kuşu Sayımları 2019”, Ankara, 2019.

11. Mori Y, Kawanishi S, Sodhi NS. Yamagishi S. The relationship between waterfowl assemblage and environmental properties in dam lakes in central Japan: implications for dam management practice. Ecology and Civil Engineering, c. 3, sy 1, (2000) 103-112.

12. Halil S. Oğurlu İ. Ertuğrul ET. Karacaören I baraj gölünün kuş faunasi. Mehmet Akif Ersoy Üniversitesi Fen Bilimleri Enstitüsü Dergisi, c. 9, sy 1 (2018) 22-28.

13. Sönmez ME. Kılıç Z. Benefıts Of Dams For The Ecosystem: The Sample Of Karkamıș Dam (Turkey), in: Gâștescu P, Marszelewski W, Brețcan P. (Eds.). 2nd International Conference - Water resources and wetlands Conference Proceedings. Paper presented at 2nd International Conference - Water resources and wetlands, Tulcea (Romania), 11-13 September. Romanian Limnogeographical Association, Dâmbovița, pp. 432-438, 2014.

14. Kılıç DT, Eken G. Türkiye’nin Önemli Kuş Alanları 2004 Güncellemesi, Doğa Derneği, Ankara, 2004.

15. Limak, “Obruk Baraj1 ve HES”. 2009. http://www.limak.com.tr/ sektorler/insaat/projeler/tamamlanan-tum-projeler/barajlar/ obruk-baraji-ve-hes (access date: August, 22, 2020).

16. Heinzel H, Fitter R, Parslow J, Boyla A. Türkiye'nin ve Avrupa'nın kuşları: Kuzey Afrika ve Ortadoğu dahil, Doğal Hayatı Koruma Derneği, İstanbul, 2002.

17. Porter RF, Christensen S, Schiermacker-Hansen P. Türkiye ve Ortadoğu'nun Kuşları, Uzerler Matbaası, Ankara, 2009.

18. Bibby CJ, Burgess ND, Hill DA, Mustoe S. Bird census techniques. Elsevier, 2000.

19. Gregory RD, Gibbons DW, Donald PF. Bird census and survey 
techniques, in: Sutherland WJ, Newton I, Green R (Eds.). Bird ecology and conservation, Oxford University Press, Oxford, pp 17-56, 2004.

20. IUCN. “The IUCN Red List of Threatened Species”. Version 2020-3. https://www.iucnredlist.org. Downloaded on [28.12.2020]

21. Bern Convention, (1979): Bern Convention: Convention on the Conservation of European Wildlife and Natural Habitats, 19/09/1979 https://www.coe.int/en/web/conventions/full-list/-/ conventions/treaty/104 (06/01/2020)

22. Erciyas Yavuz K, Kartal E. Türkiye Kıș Ortası Su Kuşu Sayımları
2011. Ondokuz Mayıs Üniversitesi Yayınları, Samsun, 2012.

23. Erciyas Yavuz K, İsfendiyaroğlu S. 2012 Türkiye Kış Ortası Su Kuşu Sayımları. Doğa Derneği, İzmir, 2013.

24. Ugış A, Akkuzu E, Evcin Ö. Kastamonu Yöresi Beyler ve Karaçomak Baraji Gölü Sucul Kuşları. Kastamonu Univ., Journal of Forestry Faculty 16 (2016) (2): 447-462.

25. Saygili F, Yiğit N, Bulut Ş. The spatial and temporal distributions of waterbirds in Lakes Akşehir-Eber and Lake Köyceğiz in western Anatolia, Turkey-a comparative analysis. Turkish Journal of Zoology 35 (2011) 467-480. 